\title{
KARAKTERISTIK SIFAT KIMIA BIJI KOPI ARABIKA DENGAN BEBERAPA METODA PENGOLAHAN di KABUPATEN SIMALUNGUN PROVINSI SUMATERA UTARA
}

\author{
CHARACTERISTICS OF CHEMICAL PROPERTIES \\ OF ARABICA COFFEE SEEDS WITH SEVERAL \\ PROCESSING METHODS IN SIMALUNGUN \\ REGENCY NORTH SUMATRA PROVINCE
}

\author{
RETMONO AGUNG WINARNO ${ }^{1 *}$, MAWAR INDAH BR PERANGIN- \\ ANGIN $^{2}$, NICO V. SEMBIRING ${ }^{3}$ \\ Politeknik Pembangunan Pertanian Medan \\ Jl. Binjai Km. 10 Medan, Sumatera Utara, Indonesia \\ *e-mail :ra_winarno@yahoo.co.id
}

\begin{abstract}
Coffee in North Sumatra have an important meaning in the socio-economic aspects of people's lives. One of the problems with developing coffee in Simalungun is the low quality of products. Determinants of coffee quality are influenced by geographical indications of the origin of coffee and how the coffee is processed. The purpose of this study was to determine the chemical characteristics of coffee beans produced from several locations in Simalungun Regency, North Sumatra with various coffee processing methods. The material used is red cherry Arabica coffee fruit taken from several locations, namely Raya District, Purba District and Dolok Pardamean District, with a variety of processing methods (dry method, semi-wash method, full-wash method, and honey method). The observed parameters where the chemical characteristics of coffee bean, including water content, caffeine content, ash content, and free fatty acid content. The results showed that the characteristics of the chemical properties of coffee beans produced by various processing methods were not different. Caffeine levels of coffee beans ranged from $7808.71 \mathrm{mg} / \mathrm{kg}$ the lowest to the highest $10422.11 \mathrm{mg} /$ $\mathrm{kg}$. Ash content ranged from $3.71 \%$, the lowest to the highest $4.4 \%$. Free fatty acid content from three district an average was $0.06 \%$.
\end{abstract}

Keywords: coffee processing, chemical characteristics, caffeine, free fatty acid

\begin{abstract}
ABSTRAK
Tanaman kopi di Sumatera Utara mempunyai arti penting dalam aspek kehidupan sosial ekonomi masyarakat. Salah satu permasalahan pengembangan kopi di Simalungun adalah kualitas produk yang rendah. Penentu kualitas kopi dipengaruhi oleh indikasi geografis asal kopi dan bagaimana proses pengolahan kopi tersebut. Tujuan penelitian ini untuk mengetahui karakteristik sifat kimia biji kopi yang dihasilkan dari beberapa lokasi di Kabupaten Simalungun, Sumatera Utara dengan berbagai metode pengolahan kopi. Bahan yang digunakan yaitu buah kopi arabika gelondong merah (red cherry) yang diambil dari beberapa lokasi, yaitu Kecamatan Raya, Kecamatan Purba dan Kecamatan Dolok Pardamean, dengan variasi metode pengolahan (metode kering, metode semi basah (semi wshed), metode basah (Full washed), dan metode honey kopi). Parameter yang diamati karakteristik kimia biji kopi, meliputi kadar air, kadar kafein, kadar abu, dan kadar asam lemak bebas. Hasil penelitian menunjukkan bahwa karakteristik sifat kimia biji kopi yang dihasilkan dengan berbagai metode pengolahan tidak berbeda. Kadar kafein biji kopi berkisar antara 7808,71 mg/Kg yang terendah hingga yang tertinggi 10422,11 mg/Kg pad Kecamatan Raya dengan perlakuan semi basah. Kadar abu biji kopi berkisar antara 3,71\% yang terendah didapatkan dari kecamatan Dolok Panderman hingga yang tertinggi 4,4\%. Kecamatan raya Kadar asam lemak bebas biji kopi rata-rata yang berasal dari tiga kecamatan sebesar 0,06\% kecamatan Raya.
\end{abstract}

Kata Kunci : metode pengolahan kopi, sifat kimia, kafein, asam lemak bebas 


\section{PENDAHULUAN}

\section{Latar Belakang}

Di Sumatera Utara (Sumut), tanaman kopi mempunyai arti penting dalam aspek kehidupan sosial ekonomi masyarakat (Saragih \& Harmain, 2021). Selain penghasil devisa, kopi juga menjadi ladang tenaga kerja dan sumber pendapatan utama petani. Pola konsumsi yang tinggi membuat produksi kopi tidak mampu memenuhi permintaan (Ghaffar et al, 2015). Usaha intensifikasi dilakukan di beberapa daerah yaitu Kabupaten Simalungun, Humbang Hasundutan, Mandailing Natal, Tapanuli Utara, Toba Samosir dan Dairi seluas 7.500 ha. Banyak kebijakan yang dikeluarkan dan telah dilakukan pemerintah dalam mengembangkan kopi Sumatera Utara. Peningkatan daya saing tanaman kopi juga dilakukan mulai di on farm, panen, pengolahan dan kemasan (Lestari Baso \& Anindita, 2018).

Peluang dalam pengembangan pengolahan kopi didalam negeri khususnya di Sumatera Utara masih cukup besar karena potensi konsumsi kopi, dan permintaan kopi dunia terus menanjak (Sitanggang, 2013). Salah satu strategi dalam mendukung pengembangan kopi adalah proses pengolahannya, mempertahankan mutu kopi yang baik melalui proses pengolahan yang tepat (Priantara, Mulyani, \& Setriawan, 2017). Beberapa metode pengolahan kopi dapat dilakukan dengan metode pengolahan kering, pengolahan basah, pengolahan semi basah dan honey kopi. Winarno (2020) mengidentifikasi beberapa permasalahan pengembangan kopi di Simalungun salah satunya adalah kualitas produk yang rendah. Penentu kualitas kopi dipengaruhi oleh indikasi geografis asal kopi dan bagaimana proses pengolahan kopi tersebut.

Mutu kopi yang dihasilkan petani umumnya masih rendah karena pengolahan pasca panen masih menghasilkan kopi asalan yaitu kadar air relatif tinggi dan masih tercampur dengan bahan cemaran lainnya (Fathoni, 2020). Petani pekebun kopi lebih memilih penanganan biji kopi secara kering, hal ini dikarenakan sesuai dengan produksi biji kopi yang diperoleh dari lahan yang tidak cukup luas, alat yang digunakan sederhana, dan biaya investasi rendah (Novita et al, 2010). Namun, penanganan biji kopi cara kering menghasilkan mutu biji yang kurang baik, terlebih apabila diterapkan pada jenis kopi arabika (Hayati, Marliah, \& Rosita, 2012).

Sampai saat ini kajian tentang karakteristik sifat kimia biji kopi yang dihasilkan dari beberapa metoda pengolahan pada buah kopi arabika di berbagai daerah sentra penghasil kopi di Sumatera Utara belum ada, sehingga kajian mengenai karakteristik sifat kimia biji kopi arabika dari beberapa kecamatan di kabupaten Simalungun dengan beberapa metode pengolahan perlu dilakukan dalam mendukung peningkatan mutu biji kopi arabika perkebunan rakyat, terutama di kabupaten Simalungun.

\section{MATERI DAN METODE}

Penelitian ini dilaksanakan di Kabupaten Simalungun, Sumatera Utara. Bahan yang digunakan yaitu buah kopi arabika gelondong merah (red cherry) dari beberapa lokasi di Simalungun yaitu Kecamatan Raya, Kecamatan Purba, dan Kecamatan Dolok Pardamean. Peralatan yang digunakan yaitu ember, tampah, pulper, karung goni, neraca analitik, dan mesin huller. Kegiatan penanganan pasca panen, fermentasi dan pengeringan dilakukan di kabupaten Simalungun, selanjutnya pengujian sifat kimia biji kopi meliputi kadar air, kadar kafein, kadar abu dan kadar asam lemak bebas, dilakukan di Laboratorium Saraswanti Indo Genetech, Bogor. Dimana masingmasing kecamatan diambil 3 sampel.

Metode yang digunakan dalam penelitian ini adalah Rancangan Acak Kelompok yang disusun secara faktorial dengan dua faktor yaitu Metode Pengolahan (A) dan Asal Kopi (B), masing-masing perlakuan dilakukan 3 kali ulangan, perlakuan yang dipakai adalah :

1. Metode Pengolahan :

A1 : Metode Kering

A2 : Metode Semi Basah (Semi washed)

A3 : Metode Basah (Full washed)

A4 : Honey Kopi

2. Asal Kopi :

B1 : Kecamatan Raya

B2 : Kecamatan Purba

B3 : Kecamatan Dolok Pardamean 
Kombinasi perlakuan yang didapatkan yaitu :

Penjelasan hasil analisa dilakukan secara deskriptif. Parameter yang diamati meliputi karakteristik sifat kimia biji kopi dari berbagai metode pengolahan. Mekanisme pengujian yang dilakukan yaitu :

\section{Kadar Air}

Penentuan kadar air biji kopi mengacu pada SNI 2907-2008: Biji Kopi, dengan prosedur sebagai berikut :

a. Timbang 10 gram sampel ke kotak timbang yang telah diketahui bobot kosongnya.

b. Keringkan di dalam oven $150^{\circ} \mathrm{C}$ selama 16 jam.

c. Dinginkan didalam desikator

d. Timbang

e. Ulangi pemanasan sampai dengan bobot tetap.

Kadar air dihitung sebagai berikut :

$$
\text { (B-C) } \times 100 \%
$$

Keterangan :

$\mathrm{A}=$ bobot sampel

$\mathrm{B}=$ bobot sampel + kotak timbang

$\mathrm{C}=$ bobot sampel + kotak timbang setelah pemanasan

\section{Kadar Kafein}

Penentuan kadar kafein biji kopi mengacu pada SNI 01-3542-2004: SNI Kopi Bubuk, dengan prosedur sebagai berikut :

A. Preparasi Sampel

1. Buat deret standar kafeun minimal 6 detik konsentrasi ke dalam labu ukur $10 \mathrm{~mL}$ degan rentng konsentrasi $0.25-100 \mathrm{mg} / \mathrm{L}$

2. Timbang 1 gram contoh ke dalam piala gelas $100 \mathrm{~mL}$

3. Larutkan dengan $\pm 40 \mathrm{~mL}$ akuabides, tambahkan $1 \mathrm{~mL}$ larutan $\mathrm{Pb}$ asetat $23 \%$

4. Panaskan dalam penangas air pada suhu $100^{\circ} \mathrm{C}$ selama 15 menit, kemudian di dinginkan pada suhu kamar

5. Pindahkan larutan contoh ke dalam labu ukur $100 \mathrm{~mL}$ dan bilas piala gelas dengan akuabides sampai larutan contoh masuk seluruhnya ke dalam labu ukur $100 \mathrm{~mL}$, kemudian tepatkan sampai pada garis, dan homogenkan

6. Pindahkan larutan sampel ke dalam tube $2 \mathrm{~mL}$, sentrifugasi pada kecepatan 14000 rpm selama 3 menit

7. Saring larutan dengan syringe filter GHP/RC/CA?PVDF $0.45 \mu \mathrm{m} \quad \mathrm{ke}$ dalam viral $2 \mathrm{ml}$

B. Suntikkan ke sistem HP

Kondisi Instrumen

Kolom: Lichrosper RP-18

Fase gerak: Metanol : akubides (35:65)

Laju alir : $0,75 \mathrm{~mL} /$ menit

Volume injeksi: $10 \mathrm{uL}$

Detektor: PDA, $\lambda 272 \mathrm{~nm}$

Suhu kolom: $35^{\circ} \mathrm{C}$

Sampling rate: 10 point/sec

C. Interpretasi Hasil

Kadar kafein dalam sampel dihitung dan ditetapkan menggunakan

kurva kalibrasi yang sesuai dengan luas area yang masuk ke dalam kurva standar, dengan garis lurus : $\mathrm{Y}=\mathrm{bx}+\mathrm{a}$

Kadar kafein, $m g \mathrm{Kg}=$ (Luas area-intersept)/slope $x$ Volume akhir (mL) $\mathrm{x}$ fp

Bobot contoh (g)

\section{Kadar Abu}

Penentuan kadar abu biji kopi mengacu pada SNI 01-2891-1992 Butir 6.1. SNI Cara Uji Makanan dan Minuman, dengan prosedur sebagai berikut :

a. Timbang 2-3 gram ke dalam cawan porselin yang telah diketahui bobotnya

b. Lakukan proses pengarangan hingga asap hilang

c. Abukan dalam tanur pada suhu $550^{\circ} \mathrm{C}$ hingga pengabuan sempurna ( \pm 4 jam)

d. Dinginkan didalam desikator

e. Timbang hingga diperoleh bobot tetap

Kadar abu (\%) dihitung sebagai berikut :

$$
\frac{(\mathrm{C}-\mathrm{A})}{(\mathrm{B})} \times 100 \%
$$

Keterangan :

$\mathrm{A}=$ bobot cawan kosong $(\mathrm{g})$

$\mathrm{B}=$ bobot sampel $(\mathrm{g})$

$\mathrm{C}=$ bobot tetap cawan + sampel setelah pemijaran $(\mathrm{g})$ 


\section{Kadar Asam Lemak Bebas}

Penentuan kadar asam lemak bebas biji kopi dilakukan dengan prosedur sebagai berikut :

A. Standarisasi Larutan $\mathrm{KOH}$ atau $\mathrm{NaOH} 0.1$ $\mathrm{N}$

Timbang $25 \mathrm{mg}$ asam oksalat ke dalam erlenmever $100 \mathrm{~mL}$. Setelah itu larutkan $50 \mathrm{~mL}$ akuades dengan ditambahkan 3-5 tetes indikator PP $1 \%$. Setelah itu tirasi dengan larutan $\mathrm{KOH} 0.1 \mathrm{~N}$ hingga titik akhir titrasi (merah muda seulas).

B. Preparasi Sampel

Tirasi dengan larutan $\mathrm{KOH} 0.1 \mathrm{~N}$ hingga titik akhir tirasi (merah muda seulas). Tutup etraction thrimble dengan kapas. Setelah itu ekstraksi dengan n-heksana selama 16 jam menggunakan alat ekstraksi minyak/lemak (soxxtech atau sokhlet). Uapkan pelarut nheksana sampai hanya tersisa residu lemak (merah muda seulas). Setelah itu larutkan residu lemak dengan $50 \mathrm{~mL}$ etanol $95 \%$ panas dan tambahkan 3-5 tetes indikator PP $1 \%$. Tirasi dengan larutan $\mathrm{KOH} 0.1 \mathrm{~N}$ atau $\mathrm{NaOH}$ $0.1 \mathrm{~N}$ hingga titik akhit titrasi (merah muda seulas). Lakukan pengerjaan blanko.

C. Interpretasi Hasil

i. Perhitungan Normalitas $\mathrm{KOH}$ atau $\mathrm{NaOH}$ $0.1 \mathrm{~N}$

Normalitas $\mathrm{KOH} / \mathrm{NaOH}(\mathrm{N})=$ $\mathrm{m}$

$$
\mathrm{V}_{2} \times f p \times 63
$$

Keterangan :

$$
\begin{array}{ll}
\mathrm{m} & =\text { bobot standar primer }(\mathrm{mg}) \\
\mathrm{Vp} & =\text { volume penitar }(\mathrm{mL}) \\
\mathrm{fp} & =\text { faktor pengenceran }
\end{array}
$$

ii. Perhitungan Kadar Asam Lemak Bebas Asam Lemak Bebas (\%)=

$\left(\mathrm{V}_{\mathrm{p}}-\mathrm{V}_{\mathrm{b}}\right) \times \mathrm{Np} \times \mathrm{BM}$ as. lemak $\times \mathrm{fp}$

$$
10 \times \mathrm{W}_{\text {spl }}
$$

Keterangan :

Wspl = bobot sampel (gram)

$\mathrm{Vp}=$ volume larutan $\mathrm{KOH}$ atau $\mathrm{NaOH}$ pada penitaran sampel $(\mathrm{mL})$

$\mathrm{Vb}=$ volume larutan $\mathrm{KOH}$ atau $\mathrm{NaOH}$ pada penitaran blanko $(\mathrm{mL})$

$\mathrm{Np}=$ normalitas larutan $\mathrm{KOH}$ atau $\mathrm{NaOH}$ $\mathrm{fp}=$ faktor pengenceran

$\mathrm{BM}=$ bobot molekul asam lemak bebas $(\mathrm{g} / \mathrm{mol})$

$$
\begin{array}{ll}
\text { Asam oleat } & =282 \\
\text { Asam palmitat } & =256 \\
\text { Asam laurat } & =200 \\
\text { Asam erukat } & =338
\end{array}
$$

\section{HASIL DAN PEMBAHASAN \\ Kadar Air}

Kadar air merupakan salah satu komponen penentu kualitas kopi yang penting. Pada saat pemanenan kadar air biji kopi bisa diatas $60 \%$ sementara untuk penyimpanan jangka panjang kadar air harus diturunkan dikisaran $12 \%$. Hasil penelitian kadar air biji kopi yang dihasilkan dengan berbagai metode pengolahan dan asal lokasi di kabupaten Simalungun dapat dilihat pada Gambar 1.

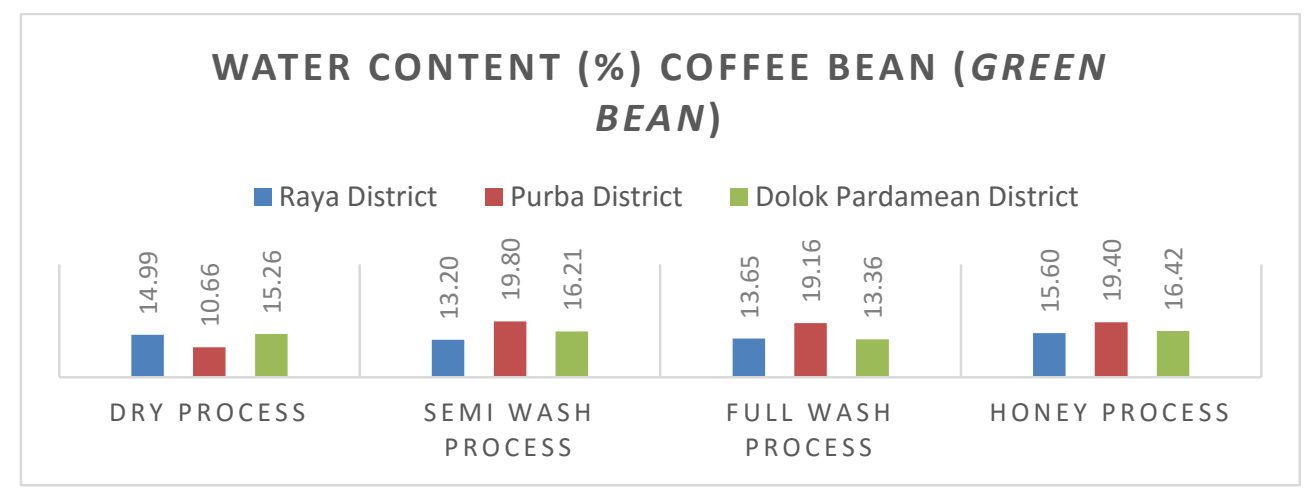

Gambar 1. Kadar air (\%) biji kopi

Gambar 1 menunjukkan kadar air biji kopi yang dihasilkan dengan berbagai metode pengolahan kopi dan asal lokasi masih cukup tinggi berada pada range $10.66 \%$ hingga yang 
tertinggi $19,80 \%$. Kadar air yang sesuai dengan SNI adalah perlakukan dengan pengolahan proses kering yang berasal dari kecamatan Purba, sementara kadar air yang lainnya masih diatas SNI. Hasil pengujian Anova didapatkan pengaruh signifikasin dengan nilai standar 5\%. Berdasarkan standar SNI biji kopi 01-2907-2008 kadar air berkisar $12-13 \%$. Masih tingginya kadar air yang diperoleh dari penelitian ini disebabkan karena proses pengeringan kurang sempurna, tingginya curah hujan pada bulan SeptemberOktober menyebabkan kurang optimalnya proses pengeringan yang dilakukan dengan secara tradisional dengan memanfaatkan energi matahari (penjemuran).

Secara visual biji kopi arabika yang dihasilkan tidak berjamur dan tidak berbau busuk sehingga masih masuk ke dalam standar SNI, walaupun setelah diuji secara kimia kadar airnya masih tinggi. Tingginya kadar air akan mempengaruhi daya simpan dan kesegaran biji kopi, semakin tinggi kadar air maka daya simpan dan kesegaran biji kopi semakin rendah dan sebaliknya semakin rendah kadar air maka daya simpan semakin tinggi. Kadar air mempengaruhi kerusakan mikroorganisme dalam suatu bahan sehingga bahan mudah berjamur. Kadar air yang tinggi pada biji kopi kalau dilanjutkan proses pengolahannya menjadi bubuk kopi, kualitas yang dihasilkan kurang baik karena semakin tinggi kadar air dapat menurunkan aroma kopi bubuk, karena senyawa-senyawa volatile kopi bubuk yang dihasilkan selama penyanraian mudah larut di dalam air, sehingga dapat mengurangi aroma kopi seduhan. Selain itu peningkatan kadar air akan merubah tekstur kopi bubuk yang ditandai dengan penggumpalan-penggumpalan pada kopi bubuk (Asiah et al, 2020).

\section{Kadar Kafein}

Komponen utama di dalam biji kopi adalah kafein, kafein merupakan zat perangsang syaraf yang sangat penting. Kandungan kafein setiap jenis kopi berbedabeda. Kadar kafein rata-rata jenis arabika sekitar 1,2\%. (Rejo, Rahayu, \& Panggabean, 2008). Hasil penelitian kadar air biji kopi yang dihasilkan dengan berbagai metode pengolahan dan asal lokasi di kabupaten Simalungun dapat dilihat pada Gambar 2.

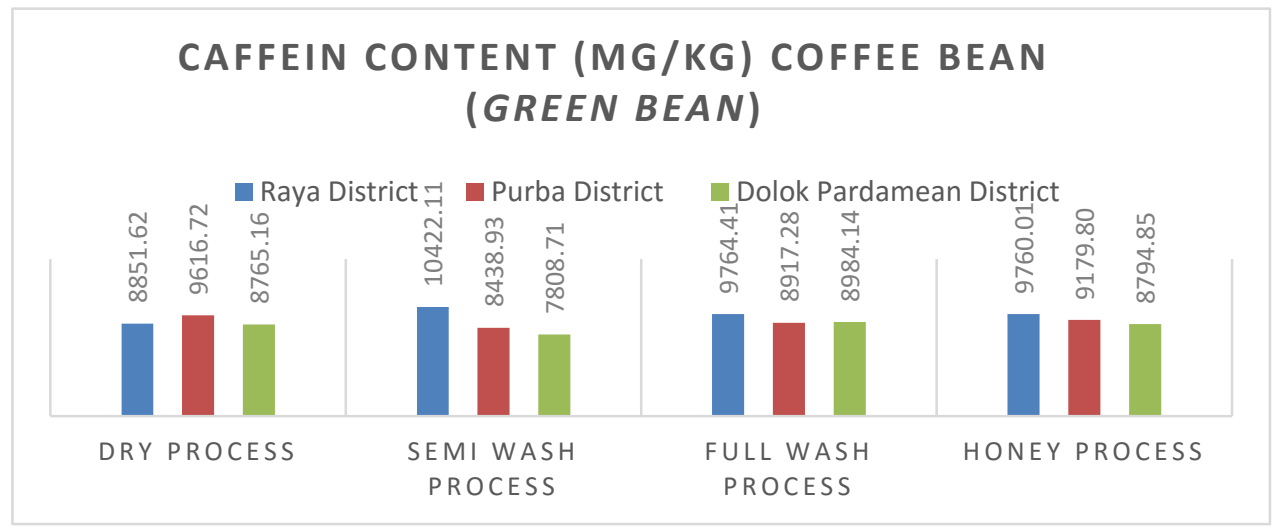

Gambar 2. Kadar kafein (mg/Kg) biji kopi

Gambar 2 menunjukkan kadar kafein biji kopi yang dihasilkan dengan berbagai metode pengolahan kopi dan asal lokasi berada pada range $7808,71 \mathrm{mg} / \mathrm{Kg}$ yang terendah hingga yang tertinggi $10422,11 \mathrm{mg} / \mathrm{Kg}$. Hasil pengujian Anova didapatkan nilai yang signifikaan 5\%. Hal ini menunjukkan bahwa dari masing-masing perlakuan dengan perbedaan lokasi kopi yang didapatkan dan proses pengolahan yang berbeda menunjukkan pengaruh yang nyata pada kadar kafein. Kadar kafein biji kopi terendah dihasilkan dari pengolahan semi basah yang berasal dari kecamatan Dolok Pardamean, sementara kadar kafein tertinggi dihasilkan dari pengolahan semi basah yang berasal dari kecamatan Raya.

Tinggi rendahnya kadar kafein umumnya digunakan sebagai pertimbangan dalam menentukan racikan pencampuran untuk resep campuran bubuk kopi. Beberapa tubuh manusia ada yang sangat peka terhadap kafein. Kafein sebenarnya hanya menyumbang citarasa bitterness kurang dari 10\%. Kafein tidak memiliki pengaruh langsung terhadap citarasa. Namun untuk beberapa jenis kopi, kafein berhubungan dengan komponen 
lainnya, seperti lemak dan asam klorogenat yang dapat mempengaruhi bitterness dan kekentalan seduhan kopi (Rejo et al., 2008).

\section{Kadar Abu}

Kadar abu merupakan unsur mineral sebagai sisa yang tertinggal setelah bahan dibakar sampai bebas unsur karbon. Kadar abu juga dapat diartikan sebagai komponen yang tidak mudah menguap tetap tinggal dalam pembakaran dan pemijaran senyawa organik. Hasil penelitian kadar abu biji kopi yang dihasilkan dengan berbagai metode pengolahan dan asal lokasi di kabupaten Simalungun dapat dilihat pada Gambar 3.

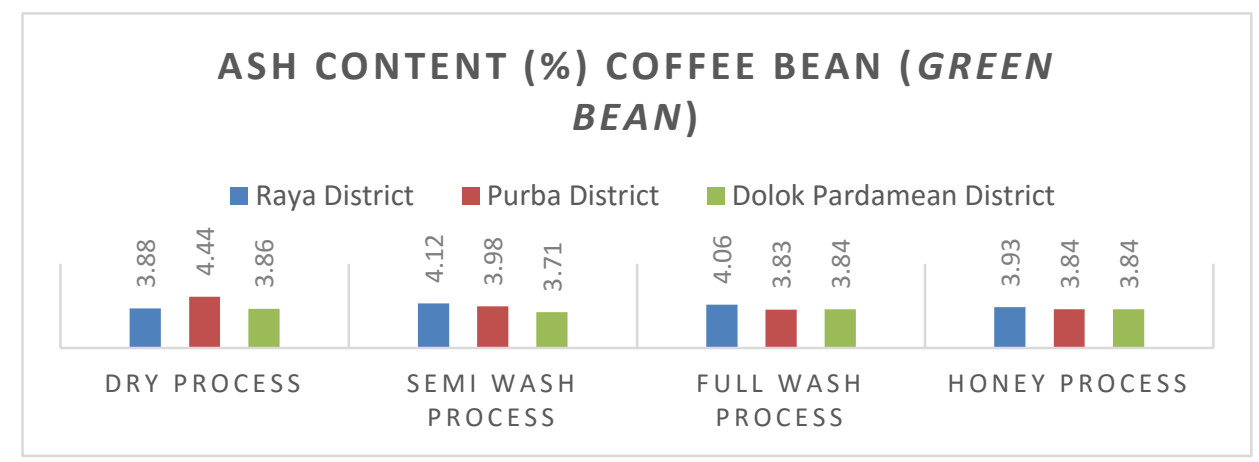

Gambar 3. Kadar abu (\%) biji kopi

Gambar 3 menunjukkan kadar abu biji kopi yang dihasilkan dengan berbagai metode pengolahan kopi dan asal lokasi berada pada range $3,71 \%$ yang terendah hingga yang tertinggi 4,4\%. Hasil uji Anova setiap perlakuan menunjukkan adanya pengaruh yang signifikan dengan nilai dibawah 5\%, dimana bahwa kopi dari berbagai daerah dan pengolahan yang berbeda memberikan pengaruh yang nyata pada kadar abu. Kadar abu biji kopi terendah dihasilkan dari pengolahan semi basah yang berasal dari kecamatan Dolok Pardamean, sementara kadar abu tertinggi dihasilkan dari pengolahan kering yang berasal dari kecamatan Raya. Kadar abu dalam biji kopi mencerminkan kandungan mineral yang terdapat dalam biji kopi. Kadar abu yang tinggi dapat diartikan kandungan mineral yang tinggi, selain itu kotoran dan sisa kulit ari juga dapat mempengaruhi kadar abu. Mutu kopi yang baik akan lebih bersih dan kandungan mineralnya tinggi sehingga kadar abu yang dihasilkan akan semakin tinggi.

\section{Kadar Asam Lemak Bebas}

(Simbolon, Pakpahan, \& MZ (2013) yang menyatakan bahwa biji kopi secara alami mengandung berbagai jenis senyawa volatil seperti aldehida, furfural, keton, alkohol, ester, asam format, dan asam asetat yang mempunyai sifat mudah menguap. Hasil penelitian kadar asam lemak bebas biji kopi yang dihasilkan dengan berbagai metode pengolahan dan asal lokasi di kabupaten Simalungun dapat dilihat pada Gambar 4.

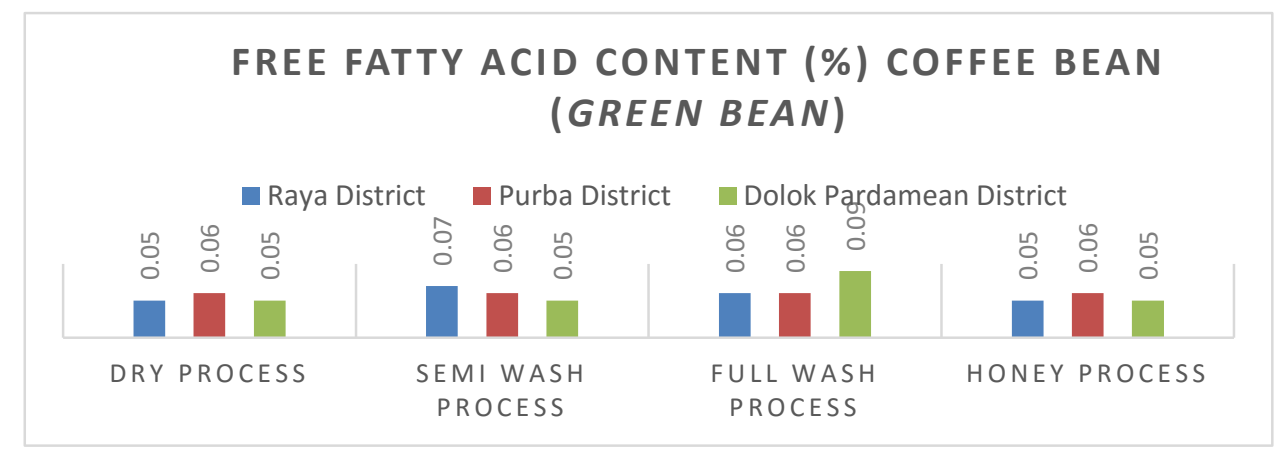

Gambar 4. Kadar asam lemak bebas (\%) biji kopi

Gambar 4 menunjukkan kadar asam lemak bebas biji kopi yang dihasilkan dengan berbagai metode pengolahan kopi dan asal lokasi berada pada range $0,05 \%$ yang terendah 
hingga yang tertinggi $0,09 \%$. Sebagian besar biji kopi yang dihasilkan mempunyai kadar asam lemak bebas yang seragam. Kadar asam lemak bebas biji kopi rata-rata yang berasal dari tiga kecamatan memiliki hasil yang sama $0,06 \%$, sementara berdasarkan dari jenis pengolahan yang dilakukan, berturut-turut nilai rata-rata kadar asam lemak bebas biji kopi yaitu, pengolahan kering $0,05 \%$, pengolahan semi basah $0,06 \%$, pengolahan basah $0,07 \%$ dan pengolahan honey 0,05\%. Hasil uji Anova menunjukkan adanya pengaruh yang signifikan, dimana perlakuan perbedaan daerah dan perbedaan pengolahan menunjukkan adanyanya pengaruh yang nyata terhadap kadar lemak bebas.

\section{KESIMPULAN}

Berdasarkan hasil penelitian menunjukkan bahwa perbedaan lokasi terbaik didapatkan pada lokasi Dolok Pardamean dengan pengelolaan semi basah. Nilai dengan nilai kadar air terendah $10,66 \%$, kadar kaefin $10422,11 \mathrm{mg} / \mathrm{Kg}$, kadar abu sebesar 3,71\%, dan kadar lemak bebas sebesar $0,06 \%$.

\section{DAFTAR PUSTAKA}

ASIAH, N., CEMPAKA, L., RAMADHAN, K., \& MATATULA, S. H. (2020). Prinsip Dasar Penyimpanan Pangan Pada Suhu Rendah. In Nasmedia.

FATHONI, I. (2020). Analisis Daya Tarik Budidaya dan Pengolahan Kopi untuk Pengembangan Agrowisata di Desa Babadan Banjarnegara. Jurnal Kawistara. https://doi.org/10.22146/kawistara.42975

GHAFFAR AL RASYID, R., JONI MURTI MULYO AJI, I., \& RUR DPA, M. M. (2015). Analisis Rantai Pasokan (Supply Chain) Kopi Rakyat Di Kabupaten Jember. Skripsi.

HAYATI, R., MARLIAH, A., \& ROSITA, F. (2012). SIFAT KIMIA DAN EVALUASI SENSORI BUBUK KOPI ARABIKA. Jurnal Floratek.

LESTARI BASO, R., \& ANINDITA, R. (2018). Analisis Daya Saing Kopi Indonesia.
Jurnal Ekonomi Pertanian Dan Agribisnis. https://doi.org/10.21776/ub.jepa.2018.002 .01 .1

NOVITA, E., SYARIEF, R., NOOR, E., \& MULATO, S. (2010). Peningkatan Mutu Biji Kopi Rakyat dengan Pengolahan Semi Basah Berbasis Produksi Bersih (Smallholder Coffee Bean Quality Improvement with Semi Wet Processing Based on Clean Production). Agrotek.

PRIANTARA, I. D. G. Y., MULYANI, S., \& SETRIAWAN, I. K. (2017). Analisis Nilai Tambah Pengolahan Kopi Arabika Kintamani Bangli. Jurnal Rekayasa Dan Manajemen Agroindustri.

REJO, A., RAHAYU, S., \& PANGGABEAN, T. (2008). Karakteristik Mutu Biji Kopi Pada Proses Dekafeinasi [Quality Characteristics Of Coffee Beans in the Decaffeination Process]. Department of Agricultural Technology Universitas Sriwijaya.

SARAGIH, J. R., \& HARMAIN, U. (2021). Faktor-faktor yang Mempengaruhi Kinerja Kewirausahaan Petani Kopi Arabika di Kecamatan Dolog Masagal, Kabupaten Simalungun, Provinsi Sumatera Utara. Journal of Regional and Rural Development Planning. https://doi.org/10.29244/jp2wd.2021.5.2.1 01-109

SIMBOLON, B., PAKPAHAN, K., \& MZ, S. (2013). Kajian Pemanfaatan Biji Kopi (Arabika) Sebagai Bahan Baku Pembuatan Biodiesel. Jurnal Teknik Kimia USU,.

SITANGGANG, J. (2013). Pengembangan Potensi Kopi Sebagai Komoditas Unggulan Kawasan Agropolitan Kabupaten Dairi. Jurnal Ekonomi Dan Keuangan.

WINARNO, R. A., \& PERANGIN-ANGIN, M. I. (2020). Karakteristik mutu dan fisik biji kopi arabika dengan beberapa pengolahan di Kabupaten Simalungun Provinsi Sumatera Utara. Jurnal Agrica Ekstensia. 